\title{
The Effect of Socially Responsible HRM on Organizational Citizenship Behavior for the Environment: A Proactive Motivation Model
}

\author{
Junqian He and Hyosun Kim * \\ Chung-Ang Business School, Chung-Ang University, Seoul 06974, Korea; reta2897@163.com \\ * Correspondence: hkim3@cau.ac.kr
}

check for updates

Citation: He, J.; Kim, H. The Effect of Socially Responsible HRM on Organizational Citizenship Behavior for the Environment: A Proactive Motivation Model. Sustainability 2021, 13, 7958. https://doi.org/10.3390/ su13147958

Academic Editor: Francisco J. Gracia

Received: 1 June 2021

Accepted: 13 July 2021

Published: 16 July 2021

Publisher's Note: MDPI stays neutral with regard to jurisdictional claims in published maps and institutional affiliations.

Copyright: (c) 2021 by the authors. Licensee MDPI, Basel, Switzerland. This article is an open access article distributed under the terms and conditions of the Creative Commons Attribution (CC BY) license (https:// creativecommons.org/licenses/by/ $4.0 /)$.

\begin{abstract}
Many organizations face the important challenges of motivating employees effectively to participate in corporate social responsibility initiatives and maintaining socially responsible human resource management practices. We examine whether socially responsible human resource management (SRHRM) practices can affect employees' social responsibility-related behaviors, such as organizational citizenship behavior for the environment (OCBE). Based on proactive motivation theory, we propose a multiple-mediation model, selecting moral efficacy, felt obligation, and empathy as the mediators. We analyzed data from a sample of 535 employees from 23 manufacturing companies in China. The results show that SRHRM practices have a significant positive effect on OCBE. We also found that moral efficacy, felt obligation, and empathy significantly mediate the effect of SRHRM practices on OCBE and that there is no significant difference among the three mediation paths. Our study suggests that organizational pursuit of the socially responsible human resource management practices is an effective pathway to make employees feel more responsible toward global sustainability.
\end{abstract}

Keywords: socially responsible human resource management; organizational citizenship behavior for the environment; moral efficacy; felt obligation; empathy; proactive motivation theory

\section{Introduction}

As environmental sustainability has become central to the survival and development of organizations in the 21st century, corporate environmental responsibility (CER), an important area of corporate social responsibility (CSR), has become an issue of widely shared concern in academia [1,2]. Where the specific CER implementation process is concerned, given that employees are usually the direct creators and producers of organizations' products and services, their environmental behavior is crucial for success [1]. Ones and Dilchert [2] found that only $13 \%$ to $29 \%$ of employees' environmental behaviors in Europe and the United States were based on organizational requirements, indicating that CER implementation depends not only on the organization's rules and regulations but also on employees' proactive participation in environmental behaviors [3]. As such, the concept of organizational citizenship behavior for the environment (OCBE), which emphasizes proactive environmental behaviors beyond the scope of formal work, has increasingly attracted scholars' attention [1,3-5]. As environmental behavior is closely related to CER at the individual level, it is highly important to study the formation mechanism of OCBE for the sustainable development of both organizations and the environment.

Previous empirical studies focusing on the antecedents of OCBE at the organizational level have found that corporate environmental policy, environmental management practices, and strategic human resource management have a positive impact on employees' performance of OCBE $[3,6,7]$. As a practical policy for organizations carrying out CSR initiatives, socially responsible human resource management (SRHRM) emphasizes the organization's concerns for the triple bottom lines of economic, social, and environmental 
performance [8,9]. Shen and Zhu [10] introduced the CSR concept into HRM practices and defined SRHRM as a new HRM practice aimed at improving employees' participation in CSR initiatives. SRHRM is recognized as an integral part of CSR initiatives and an important tool for its successful implementation [9]. SRHRM and OCBE are both positive responses to the sustainable development challenges and are highly compatible in terms of values. Thus, we explore whether organizations' SRHRM practices can promote employees' performance of OCBE in the workplace.

Furthermore, this study attempts to explore the mechanisms by which organizational SRHRM practices affect OCBE. In accordance with the proactive motivation theory [11], generating individual proactive action is a "motivated, conscious and goal-directed" process, which is driven by three proximal states that can stimulate individual proactive goal generation and striving: "can do" (expectancy), "reason to" (valence), and "energized to" (affect). When individuals' proactive motivational states are stimulated and enhanced by various contextual factors in the organization, they will be more likely to take positive behavioral responses [11]. This study captures the three proximal motivational states using constructs including moral efficacy ("can do"), felt obligation ("reason to"), and empathy ("energized to") and examines whether and how they mediate the SRHRM practices' impact on OCBE.

In summary, we explore the role of SRHRM practices on OCBE from the perspective of proactive motivation theory. We propose a multiple-mediation model with moral efficacy, felt obligation, and empathy as the mediators. We conducted empirical research in the Chinese organizational management context to explore the relationships among SRHRM, OCBE, moral efficacy, felt obligation, and empathy. We aim to offer practical guidance for organizations in promoting CSR initiatives in HRM practice and managing employees' green behavior more effectively.

\section{Literature Review and Hypothesis Development}

\subsection{Organizational Citizenship Behavior for the Environment}

Climate change is a global problem, perhaps the most urgent and the greatest challenge facing humanity. Scientists believe that the main cause of climate change is human activities, and organizations are a major channel of such activities. In response, organizations have begun to adopt formal and informal environmental management systems; however, merely relying on these systems is not enough. Rather, the successful implementation of organizational environmental protection projects depends largely on employees' voluntary participation and active cooperation [2]. Environmentally engaged employees can act as a social innovator and take part in a wide range of activities, such as participating in intrapreneurial innovation to promote environmental sustainability and creating partnerships with other stakeholders [12], hence the need to understand employees' voluntary behaviors directed toward the environment.

OCBE is a voluntary environmental behavior that has recently gained interest in this light. Extending the concept of organization citizenship behavior (OCB), Daily et al. [1] defined OCBE as "environmental efforts that are discretionary acts, within the organizational setting, not rewarded or required from the organization." Later, Boiral and Paillé [4] divided OCBE into the three categories of eco-initiatives, eco-civic engagement, and eco-helping. Eco-initiatives aim at improving environmental practice and performance. Eco-civic engagement refers to employees' voluntary participation in the organization's environmental projects and activities. Eco-helping refers to employees' willingness to help colleagues in the workplace to foster their concern about environmental issues. Paillé et al. [3] verified the feasibility of this classification through an empirical study.

There are alternative conceptualizations of employees' pro-environmental behavior, including employee green behavior proposed by Ones and Dilchert [13]. Their taxonomy of green behaviors includes (1) avoiding harm, such as prevention of pollution, (2) conserving, such as recycling, (3) working sustainably, such as changing how work is done, (4) influencing others, such as educating and training for sustainability and (5) taking initiative, such 
as initiating programs and policies. Although closely related to OCBE, employee green behaviors are different from OCBE in that they are not confined to extra-role behavior and may include behaviors in task performance. Although employee green behaviors are a meaningful construct to be studied in the context of environmental sustainability, they may differ by job and by industry considerably. For example, creating eco-friendly products may constitute regular task performance behavior in green industries. As such, employee green behaviors are not well suited to our setting covering corporations in diverse industries.

Several factors affect OCBE. First, organizational environmental policy can stimulate employees' OCBE through their environmental commitment [7]. Paillé et al. [3] found that environmental management practices increase subordinates' perceptions of organizational support and supervisor support and enhance organizational commitment, which then generates stronger OCBE through reciprocity norms. Empowerment and training can also improve enthusiasm about the environment, leading to OCBE [14,15]. In a manufacturing firm with high level of green activities, Hameed et al. [16] found that employees' perception of green HRM practice resulted in higher OCBE through green employee empowerment. Pham et al. [17] also found that green training improves OCBE among employees in the hotel industry. Erdogan et al. [15] also showed that organizations' environmental enthusiasm promotes environmental protection attitudes and OCBE.

Second, leadership may affect subordinates' OCBE as well. Higher levels of consciousness among managers entail greater employee participation in ecological initiatives and ecological help [18,19]. Graves et al. [20] demonstrated that environmental transformational leadership can promote employees' environmental behaviors. Han et al. [19] also found that responsible leadership promoted OCBE through identification with the leader. Luu [21] found that environmentally specific servant leadership strengthens the relationship between green $\mathrm{HR}$ practices and OCBE.

Finally, individual characteristics may also affect OCBE. Employees may differ in terms of environmental awareness [22], environmental passion [23], and value orientation toward environmental problems [24], which could lead to different degrees of OCBE. Individual differences are often found to moderate the relationship between environment management practice and OCBE [25] and the relationship between leadership and OCBE [26].

\subsection{Employee Perception of SRHRM}

Since Bowen [27] first proposed the concept of corporate social responsibility (CSR) in the 1950s, it has attracted much attention from academics and practitioners. Per Carroll's [28] definition, CSR means that an organization should not only achieve economic goals and fulfill legal responsibilities but also consider their ethical and discretionary responsibilities to employees and external stakeholders, including shareholders, suppliers, customers, communities, governments, and NGOs in the process. With the extensive conceptual development of CSR and numerous relevant studies, it has increasingly been regarded as a mechanism by which organizations can achieve success and sustainable development in the long term $[29,30]$. Externally, the fulfillment of CSR not only can improve organizations' social reputation and corporate image but can also help them enter the international market and improve long-term profitability [31,32]. Internally, in the knowledge-based economy where human capital is considered the core driver of organizational competitive advantage, actively fulfilling CSR and establishing a good CSR image can help organizations attract and retain excellent talent [33-36]. Thus, the active fulfillment of CSR has far-reaching significance for organizations' long-term survival and development.

Employees are not only the object of CSR initiatives but also the backbone of organizational attempts to fulfill CSR. Organizations can promote CSR initiatives by encouraging employees' enthusiasm; concentrating their intelligence, attitude, and willpower; and building up the conducive work environment and procedures. Firms can achieve these goals by integrating the CSR concept into their human resource management practices. The concept of socially responsible human resource management (SRHRM) has gradually de- 
veloped from these needs [10,37]. There are three major components in an SRHRM system: legal compliance HRM (LCHRM), employee-oriented HRM (EOHRM), and general CSR facilitation HRM (GFHRM) [10]. LCHRM requires firms to comply with local labor laws and meet the standards set by the International Labor Organization, relating mainly to equal opportunity, working hours, health and safety, minimum wages, and the prohibitions against forced labor and child labor [38]. EOHRM emphasizes satisfying the employees' personal and family needs, going beyond the minimum legal requirements as much as possible, such as providing organizational support to employees, ensuring justice in the workplace, and satisfying employees' need for personal development. GSHRM involves the application of HRM policy and practice that enables participation in general CSR initiatives, such as recruiting CSR-oriented employees, evaluating them, and rewarding them for their CSR contributions.

It should be noted that we focus on the employee perception of SRHRM in our empirical investigation. Ahmad et al. [39] emphasized the importance of studying CSR as perceived at the individual employee level, which they dubbed as micro-level CSR (MCSR). Zhang et al. [40] studied employees at 50 companies in China and demonstrated that the effect of SRHRM on employee wellbeing varied depending on employees' attribution of corporate motives in the implementation of SRHRM. In a meta analysis, Wang et al. [41] also showed that employee's perceived CSR were related to various outcome, including organizational identification, organizational trust, and organizational commitment.

Why would employee perception of SRHRM affect OCBE? There are at least three theoretical perspectives that we can adopt to answer this question: social exchange theory, social identity theory, and conservation of resources theory. First, when firms support socially responsible practices that transcend organizational boundaries, they are more likely to be perceived as benevolent and caring, and have its actions reciprocated by employees [42]. Social exchange theory proposes that reciprocity norms are a powerful motivator for employee behavior [43]. For example, Rainerie and Paille [7] found that pro-environment management policy increased OCBE.

Second, when employees recognize that their company benefits various stakeholders through CSR initiatives, they will be more likely to identify with the company and be motivated to perform environmentally friendly behaviors in line with the company's goals, mission, and values [44], which is in line with social identity theory [45]. In a meta-analysis, Riketta [46] found that organizational identification was closely related to extra-role behavior. In a study of a major Israeli airline carrier, Mozes et al. [47] found that active participants of volunteering activities showed higher level of organizational identification than non-active participants. Tian and Robertson [48] found that employees' perceptions of CSR can affect their participation in voluntary environmental behaviors through organizational identification.

Third, SRHRM may encourage employees to engage in OCBE by providing necessary resources, such as knowledge and skills, that could enable socially responsible employee behavior. Conservation of resources theory proposes that resource acquisition could be a strong motivating factor for employee behavior, as individuals try to avoid stress that comes from resource loss [49]. In a study of tour operators in Vietnam, Luu [21] argued that green HRM may create an atmosphere of green learning among members, which could be utilized as organizational resources for green behavior. They indeed found that green HRM increased OCBE through collective green crafting. In a study of top management teams and frontline workers in China, Paille et al. [6] found that strategic HRM increased OCBE more strongly when employees perceive that the organization grants them the decision-making latitude and necessary resources to engage in pro-environmental behavior.

Based on these considerations, we propose the following hypothesis:

Hypothesis 1. SRHRM will have a positive effect on OCBE. 


\subsection{Proactive Motivation Model for SRHRM}

Scholars have always recognized that exploring the antecedents and psychological mechanisms of employee initiative is crucial for guiding the practice of organizational change [11]. Parker et al. [11] proposed proactive motivation theory and pointed out that generating individual proactive behavior is a process of cognition and motivation, and contextual variables in an organization can influence employees' personal initiative through the mediation of three proximal motivational states: "can do," "reason to," and "energized to" motivation.

First, performing proactive behaviors, which usually means setting higher goals to change the status quo, requires individuals' firm belief that they "can do" it. "Can do" motivation refers to an individuals' belief in their ability to change or adapt to the environment, which stems mainly from their self-efficacy. Just as others are likely to doubt and resist employees when they take initiative to improve their work processes in response to changing demands, individuals' proactive behaviors in the workplace often entail high psychological risks, while strong self-efficacy will enhance individuals' will to overcome these obstacles [50].

Second, a "can do" mentality may not lead to proactive behavior absent a compelling "reason to" act. In general, when there is strong regulatory guidance in the organizational context, individuals are likely to take initiative to achieve organizational goals. However, when the organizational context is fuzzy and lacks well-defined goals, individuals' proactive behavior requires greater internal drive-namely, "reason to" motivation. According to temporal construal theory, the desirability of future goals (the "why" of an action) is a stronger determinant than feasibility (the "how" of an action) when goals concern the longer term rather than the near term [51].

Lastly, to be "energized to" take initiative, individuals also must activate "hot" affective states in addition to the "cold" motivational states of "can do" and "reason to." Previous studies have shown that positive affect can broaden individuals' momentary action-thought repertoires and help them solve problems creatively, weigh the advantages and disadvantages flexibly, set more challenging proactive goals, and take the initiative to achieve these goals [11,52].

Despite the potential to explain complex problems regarding employee behavior in an organization, the role of human resource management practice in promoting employee proactivity has not been explored until recently [53]. Hong et al. [54] established an integrative multilevel model to explicate how contextual factors influence employees' subsequent personal initiative by shaping their proactive motivational states. They found that initiative-enhancing human resource management systems interact with empowering leadership to create a climate of initiative, which stimulates employees' motivational states of "can do" (role-breadth self-efficacy), "reason to" (intrinsic motivation), and "energized to" (activated positive affect), thereby driving personal initiative. Lee et al. [53] also examined how HRM practices promote three motivational states, namely, role breadth self-efficacy, felt responsibility for change, and trust in management and increase employee innovative behavior as a result.

We propose that SRHRM practices provide an important social process that affects proactive motivational states of employees, antecedents to OCBE. We further propose that SRHRM practices will evoke proactive motivational states that are moral and othercentered in nature, as SRHRM encourages employees to go beyond the narrow pursuit of self-interest. Hence, we chose moral efficacy, rather than self-efficacy, as a "can do" motivation. In the same logic, we chose felt obligation, rather than intrinsic motivation, as a "reason to" motivation. Finally, we chose empathy, which is other-centered in nature, rather than positive affectivity, as a "energized to" motivation.

Moral Efficacy: Moral efficacy refers to "the belief of individuals that they can effectively sustain moral performance and behave in accordance with moral requirements when faced with moral dilemmas" [55]. Hannah et al. [55] posited that individuals may rely on their own moral judgment to find solutions to moral dilemmas, but that they may not necessarily 
put them into practice, which may be due to a lack of confidence, thus reducing their moral intentions. The concept of moral efficacy bridges the gap between moral judgment and moral behavior and provides a new perspective on the latter's roots.

Moral efficacy can help individuals commence the series of actions needed to make correct moral decisions under specific conditions [50]. Even in facing moral dilemmas, individuals with high moral efficacy believe that they can effectively address achieve high moral performance, behaving in accordance with moral requirements [55]. Moreover, moral efficacy can give individuals the confidence to engage in prosocial behavior, facilitating belief in their ability to help others and thereby increasing their willingness to behave prosocially (e.g., OCB) [56]. Hannah et al. [55] found that moral efficacy has a positive impact on individuals' moral cognition and propensity, encouraging them to behave ethically. Xu et al. [56] found that employees' moral efficacy positively predicts their voice behavior when faced with abusive supervision. Thus, it is likely that moral efficacy encourages ethical behaviors in organizational settings, including OCBE.

Research has also shown that moral efficacy mediates the relationship between ethical leadership and various prosocial employee behaviors. Schaubroeck et al. [57] found that ethical leadership enhanced employees' moral efficacy, which led to courageous displays of ethical behaviors. Moreover, Kim and Vandenberghe [58] found that ethical leadership can have a positive impact on team ethical voice and OCB directed at the individual and the organization through team moral efficacy. In line with this, Owens et al. [56] found that a leader's moral humility can increase employees' moral efficacy, thus increasing employees' prosocial behaviors and reducing their unethical behaviors. These findings show that there is a broad consensus among scholars that moral efficacy can enhance individuals' moral behaviors.

We suggest that SRHRM will have a positive impact on OCBE, as SRHRM improves employees' moral efficacy. First, SRHRM practices link the recruitment, promotion, remuneration, and performance appraisal process with employees' social contributions, providing generous rewards and work benefits to employees with strong social performance [9]. By strengthening rewards, the organization encourages employees to behave ethically, which helps them gain more moral confidence and experience and thereby enhances their moral efficacy. Second, SRHRM provides employees with CSR-related systematic training programs, yielding opportunities to accumulate knowledge about and experience with fulfilling CSR roles [9]. Such training, including business ethics education, can increase employees' confidence in their ability to handle ethical problems in their work and can enhance their moral efficacy [59]. Third, SRHRM conveys the message to employees that the organization attaches importance to external stakeholders, including the natural environment [60]. Therefore, we expect that this practice will increase employees' willingness to engage in $\mathrm{OCBE}$, which is closely related to environmental protection and sustainable organizational development.

Felt Obligation: Felt obligation refers to "the prescriptive belief regarding whether one should care about the organization's well-being and should help the organization reach its goals" [61]. This definition includes two major components: The first is the belief that employees make business contributions and help to achieve organizational objectives, and the second is the belief that employees pay attention to and value the interests and welfare of the organization. Thus, felt obligation embodies the principle of reciprocity, which is a culturally universal social interaction principle [62,63].

Employees with strong felt obligation are more likely to believe that they owe the organization and to strive their best to help the organization achieve its goals $[63,64]$. When employees feel that the organization cares about them and demonstrates preferential treatment toward their interests, they may feel obligated to repay the organization and thus actively strive to improve their work [61]. Stronger feelings of obligation entail more active work efforts by employees, as well as their taking initiative to advance organizational interests and strategic goals. Further, Yu and Frenkel [65] found that perceived organizational support can enhance employees' task performance and creativity through felt 
obligation. Based on job demands-resources (JD-R) theory, Albrecht and Su [66] found that job resources can affect employees' work engagement through felt obligation.

Felt obligation also encourages employees to go "above and beyond" job requirements, engaging in extra-role behaviors that are beneficial to the organization and overall public welfare [61]. Felt obligation often influences employees to adopt constructive behaviors that will benefit others or other organizations and motivates employees to be "good citizens" who protect stakeholders [67]. Eisenberger et al. [61] found that perceived organizational support can enhance employees' felt obligation, inducing them to care about organizational welfare and help their organizations achieve their goals; in turn, they found that this promotes employees' affective commitment, spontaneity, and in-role performance.

SRHRM focuses on the interests of employees as important internal stakeholders and cares about their personal development needs and work-life balance [10]. In accordance with social exchange theory and reciprocity norms, when an organization adopts HRM practices that benefit its employees, employees will feel obligated to give back to the organization and will continue to conduct reciprocal social exchange [68]. Moreover, SRHRM clearly conveys to employees the significance of CSR for the organization and themselves, as well as the organization's expectations that employees contribute to CSR initiatives [9]. Such a clear responsibility-oriented value system will lead employees to believe that their work is not only for creating organizational benefits but also for benefiting society at large, thereby promoting employees' felt obligation. Thus, we argue that SRHRM practice strengthens employees' feelings of obligation to the organization.

Felt obligation may be an important psychological mechanism to explain the motivation behind employees' OCBE initiatives. Han et al. [19] empirically verified that felt obligation for constructive change, stimulated by responsible leadership, motivates employees to engage in OCBE. In fact, several scholars have explored the mediating role of perceived obligation in the relationship between leadership factors and employees' work behavior. Tian and $\mathrm{Li}$ [69] found that self-sacrificial leadership can promote employees' proactive behavior indirectly through felt obligation. Additionally, Basit [70] found that employees' trust in their supervisors can enhance their feelings of obligation and further improve work engagement. Lorinkova and Perry [71] found that group-focused transformational leadership is more likely to enhance working group members' feelings of obligation, thereby motivating helping behaviors and enhancing group performance. Therefore, we reason that SRHRM practice will promote employees' feelings of obligation to the organization and encourage them to engage in OCBE.

Empathy: Empathy refers to "the reaction of one individual to the observed experiences of another" [72]. More specifically, empathy is conceptualized as "an individual difference that involves sharing other people's feelings related to other people's well-being" [73], which comprises cognitive and emotional components [74]. Cognitive empathy refers to "an individual's ability to take the perspective of those in need," while emotional empathy refers to "an other-oriented emotional response elicited by and congruent with the perceived welfare of someone in need" [74]. Empathy is conceptually different from sympathy and compassion. Sympathy can be defined as "an emotional response stemming from the apprehension of another's emotional state or condition, which is not the same as the other's state or condition but consists of feelings of sorrow or concern for the other" [61]. Hence managers may feel sympathetic toward outraged employees without feeling outraged themselves, while taking on these actual feelings is characteristic of empathy [75]. Moreover, compassion is described as "a process involving both feeling and action" [76], which we can distinguish from empathy by its action component.

As an other-oriented affective reaction, empathy can arouse an individual's attention to others' needs and generate motivation to act in ways that benefit others [74]. Therefore, empathy has always been regarded as an important motivator of prosocial and altruistic behaviors $[77,78]$. Compared to employees with low empathy, who are insensitive to the needs of others, employees with high empathy are more likely to define OCB as an in-role behavior [79]. They will make efforts to understand other people's ideas and are more 
willing exhibit OCB. Supporting this assertion, Eisenberg et al. [61] found that individuals with high empathy tend to engage in more prosocial behaviors. Batson et al. [80] also found that empathy not only can construct a universal connection between oneself and others' emotional experience and well-being but also can enhance helping and sharing behaviors. Shao et al. [81] found that SRHRM can stimulate employees' affective empathy. Moreover, Berenguer [82] found that empathy can promote individuals' pro-environment attitudes and behaviors.

Organizations' SRHRM practices may trigger employees' empathic reactions. Affective events theory posits that specific affective events in the workplace, such as praise, will trigger specific affective reactions in employees [83]. First, SRHRM advocacy of social responsibility values may help employees pay attention to others' needs and interests and consider the social impact of their work behaviors on external stakeholders, thus generating empathy [81]. Additionally, as mentioned previously, SRHRM practice rewards employees for good social performance [9]. In this way, CSR activities can meet several psychological needs and practical interests of employees such that employees will be motivated to respond positively to SRHRM practice and show more empathy [81]. Based on this, we infer that employees will accept and support the caring values advocated by SRHRM practice, enabling them to empathize with those in need.

Considering that the social responsibility values transmitted to employees by SRHRM emphasize the environment as an important stakeholder, empathy can facilitate environmentally friendly attitudes and behaviors. We therefore infer that employees with empathy aroused by SRHRM practices will be more likely to fully consider the environmental impact of their behaviors and therefore will engage in OCBE, which is conducive to environmental protection. Based on this reasoning, we propose the following hypotheses:

Hypothesis 2. Moral efficacy will partially mediate the positive relationship between SRHRM and $O C B E$.

Hypothesis 3. Felt obligation will partially mediate the positive relationship between SRHRM and $O C B E$.

Hypothesis 4. Empathy will partially mediate the positive relationship between SRHRM and OCBE.

Figure 1 summarizes the hypotheses tested in this study.

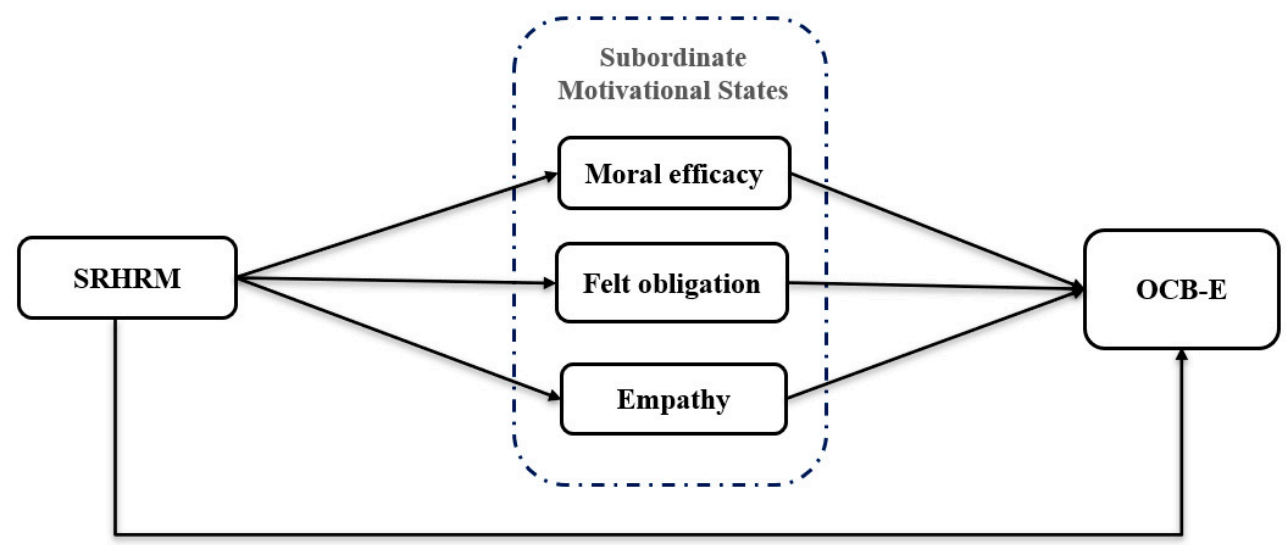

Figure 1. Research model. SRHRM: Socially responsible human resource management. OCBE: Organizational citizenship behavior for the environment.

\section{Research Methodology}

\subsection{Participants and Procedure}

We selected employees working for companies that actively engage in social responsibility initiatives as our survey participants so that employees could obtain more objective 
information about the company's SRHRM practice. To recruit eligible participants, we first contacted the HR managers of 30 companies to check their SRHRM practices. Seven of the companies either had no adequate knowledge of SRHRM or were otherwise disinclined to participate in the study, leaving us with 23 companies.

The HR managers reviewed the content and procedures and granted permission to conduct the survey during working hours, providing us with the email addresses of randomly selected employees from each department. Ultimately, we recruited 656 employees from 23 manufacturing companies in Beijing, Shanghai, Guangzhou, Jiangsu, Zhejiang, and Anhui provinces in China to participate in our survey.

We used a self-report questionnaire method of data collection. To reduce potential common variance, we separated the independent variable and the dependent variables and used a longitudinal research design, distributing and collecting questionnaires over a twoweek interval [84] during October and November 2020. Due to the COVID-19 pandemic, we conducted the whole survey process online.

At Time 1, we emailed participants a link to the first questionnaire, which measured variables including SRHRM, moral efficacy, empathy, demographic characteristics, and other control variables. Two weeks later, at Time 2, we emailed participants another link to the second questionnaire, which measured OCBE. To match the two questionnaires, we asked participants to fill in the last four digits of their primary phone number. We recovered a total of 584 successfully matched questionnaires, from which we excluded 49 as invalid. The remaining 535 valid questionnaires constituted the final sample, giving $81.55 \%$ valid questionnaire returns. We compared the final sample and the sample of observations lost due to attrition and found no significant difference.

Table 1 displays the demographic characteristics of the final sample. In general, the sample data were reasonably distributed on various characteristics, which is conducive for subsequent research.

Table 1. Sample characteristics $(n=535)$.

\begin{tabular}{|c|c|c|c|}
\hline Variable & Dimension & Frequency & Percent (\%) \\
\hline \multirow{2}{*}{ Gender } & Male & 280 & $52.3 \%$ \\
\hline & Female & 255 & $47.7 \%$ \\
\hline \multirow{5}{*}{ Age } & Less than 20 & 61 & $11.4 \%$ \\
\hline & $20 \sim 30$ & 159 & $29.7 \%$ \\
\hline & $31 \sim 40$ & 189 & $35.3 \%$ \\
\hline & $41 \sim 50$ & 118 & $22.1 \%$ \\
\hline & More than 50 & 8 & $1.5 \%$ \\
\hline \multirow{4}{*}{ Education Level } & High school graduate or below & 40 & $7.5 \%$ \\
\hline & College degree & 213 & $39.8 \%$ \\
\hline & Bachelor's degree & 229 & $42.8 \%$ \\
\hline & Master's degree or above & 53 & $9.9 \%$ \\
\hline \multirow{5}{*}{ Organizational Tenure } & Less than 1 year & 81 & $15.1 \%$ \\
\hline & $1 \sim 3$ years & 156 & $29.2 \%$ \\
\hline & $4 \sim 6$ years & 211 & $39.4 \%$ \\
\hline & 7 10 years & 72 & $13.5 \%$ \\
\hline & More than 10 years & 15 & $2.8 \%$ \\
\hline \multirow{4}{*}{ Job Position } & General staff & 357 & $66.7 \%$ \\
\hline & Junior manager & 142 & $26.5 \%$ \\
\hline & Intermediate manager & 29 & $5.4 \%$ \\
\hline & Senior manager & 7 & $1.3 \%$ \\
\hline
\end{tabular}

\subsection{Operational Definitions and Measurements}

OCBE: In this study, organizational citizenship behavior for the environment (OCBE) is defined as "individual and discretionary social behaviors that are not explicitly recognized by the formal reward system and that contribute to a more effective environmental 
management by organizations" [4]. We used Boiral and Paillé's [4] 10-item OCB-E scale, which has been used in the Chinese cultural context. Sample items include "I voluntarily carry out environmental actions and initiatives in my daily work activities," "I actively participate in environmental events organized in and/or by my company," and "I encourage my colleagues to adopt more environmentally conscious behavior." All items utilized a 7-point Likert scale ranging from 1 (strongly disagree) to 7 (strongly agree).

Perceived SRHRM: Socially responsible human resource management (SRHRM) is defined as "a series of human resource management practices initiated by organizations to promote and reward employees' active participation in CSR activities beneficial to external stakeholders, including recruiting and retaining socially responsible employees, providing CSR training, and taking account of employees' social contributions in promotion, performance appraisal, and remuneration" $[9,10]$. We used the six-item SRHRM scale adapted and validated by Shen and Benson [9]. Sample items include "My company considers employee social performance in performance appraisals," "My company considers candidates' general attitudes toward CSR in selection," and "My company provides CSR training to develop employees' skills in stakeholder engagement and communication." All items utilized a 7-point Likert scale ranging from 1 (strongly disagree) to 7 (strongly agree).

Moral Efficacy: Moral efficacy is defined as "an individual's belief in his/her abilities to actively and positively address ethical issues that may arise in the workplace and to overcome obstacles encountered in developing and implementing ethical solutions to ethical dilemmas" [55]. We used the nine-item moral efficacy scale adapted and validated by May et al. [59]. Sample items include "I am confident in my ability to analyze an ethical problem to find a solution," "I am confident in my ability to formulate an evaluation of the different sides of an ethical issue," and "I am confident in my ability to formulate strategies for overcoming resistance to your proposed solutions to ethical problems at work."

Felt Obligation: Felt obligation is defined as "an individual's prescriptive belief regarding whether he or she should care about the organization's well-being and should help the organization achieve its goals" [61]. To measure felt obligation, we administered the seven-item felt obligation scale developed and validated by Eisenberger et al. [61]. Participants rated whether they feel obligated to care about the organization and to help it achieve its goals on a 7-point Likert scale. Sample items include "I feel a personal obligation to do whatever I can to help the organization achieve its goals," "I have an obligation to the organization to ensure that I produce high-quality work," and "I would feel an obligation to take time from my personal schedule to help the organization if it needed my help." Eisenberger et al. [61] reported a Cronbach's alpha value of 0.88 for this scale.

Empathy: Empathy is defined as "an other-oriented emotional response that is elicited by and congruent with the perceived welfare of someone in need when taking the perspective of those in need" [73]. We administered the 10-item abbreviated empathy scale adapted and validated by Dietz and Kleinlogel [75] to measure empathy. Participants rated their ability to put themselves in the shoes of someone in need and their actual feelings when seeing those in need on a 7-point Likert scale. Sample items include "Before criticizing somebody, I try to imagine how I would feel if I were in their place," "When I'm upset at someone, I usually try to 'put myself in his shoes' for a while," and "I often have tender, concerned feelings for people less fortunate than me." Tian and Robertson [48] have demonstrated strong evidence of the scale's reliability and validity in the Chinese cultural context.

Since the original scales were in English and the survey participants were Chinese, the back translation procedure recommended by Brislin [85] was adopted to translate the scales into Chinese and then back into English to ensure the accuracy of the scales' meaning.

\subsection{Control Variables}

We measured several demographic variables based on previous studies, including gender, age, education level, organizational tenure, and job position, as they may affect individuals' willingness to engage in extra-role behaviors [86]. 


\subsection{Analysis Methods}

We used SPSS 25.0 (including the PROCESS macro, version 3.4) and AMOS 23.0 to analyze the valid sample data. First, we conducted the Harman single-factor test to check for common method variance. Second, we performed exploratory factor analysis (EFA) and confirmatory factor analysis (CFA) to test the construct validity of the measures used in this study. Then, we computed Cronbach's alpha coefficients to confirm the measures' internal consistency. Finally, we used hierarchical multiple regression to test all research hypotheses, as well as to confirm whether our proposed moderated multiple-mediation model was tenable. To test the multiple mediating mechanism between SRHRM and OCBE, we utilized Model 4 in the PROCESS [87]. We entered all control variables into the model and set the number of bootstrap samples to 5000 . Then, we utilized the bias-corrected bootstrapping method to conduct tests at the $95 \%$ confidence level.

\section{Results}

\subsection{Common Method Variance Test}

Common method variance (CMV) is defined as "systematic error variance shared among variables measured with, and introduced as, a function of the same method and/or source" [88]. We used the Harman single-factor test to check for common method variance. The principal component analysis extracted a total of seven factors with eigenvalues greater than 1 , and the total variance extracted by the first principal factor was $31.097 \%$, which is less than the threshold of 50\% recommended by Hair et al. [89]. These results indicated that there were no common method variance issues in this study.

\subsection{Validity and Reliability Analysis}

We conducted KMO and Bartlett's test of sphericity on the sample data. As illustrated in Table 2, the KMO value was 0.943 (much greater than 0.5 ), statistically significant at $p<0.001$. This indicated that the sample data were suitable for factor analysis.

Table 2. KMO and Bartlett's Test.

\begin{tabular}{ccc}
\hline \multicolumn{2}{c}{ Kaiser-Meyer-Olkin Measure of Sampling Adequacy } & $\mathbf{0 . 9 4 3}$ \\
\hline \multirow{3}{*}{ Bartlett's Test of Sphericity } & Approx. Chi-Square & 13384.452 \\
& $d f$ & 780 \\
& Significance & 0.000 \\
\hline
\end{tabular}

Next, we conducted EFA with the varimax rotation method to obtain the rotated component matrix for interpretation. Consequently, we eliminated one moral efficacy scale item and one empathy scale item. Then, to further confirm the fit between the measured data and the theoretical frameworks of the measurements, we conducted CFA.

As shown in Table 3, the standardized factor loadings for all items exceeded 0.50, and the loadings of eco-initiatives, eco-civic engagement, and eco-helping on the firstorder dimension of the second-order variable OCBE exceeded 0.70. Moreover, the CR and AVE values for each construct exceeded 0.70 and 0.50 , respectively. The CR values of all constructs exceeded the corresponding AVE values. These results indicated that all constructs had good internal consistency and convergent validity. 
Table 3. Results of Confirmatory Factor Analysis.

\begin{tabular}{|c|c|c|c|c|c|c|c|}
\hline Construct & Indicator & Factor Loading & SMC & $t$-Value & $p$-Value & CR & AVE \\
\hline \multirow{3}{*}{ OCB-E } & Eco-initiatives & 0.775 & 0.595 & - & - & \multirow{3}{*}{0.795} & \multirow{3}{*}{0.564} \\
\hline & Eco-civic Engagement & 0.705 & 0.497 & 11.315 & $* * *$ & & \\
\hline & Eco-helping & 0.771 & 0.600 & 11.899 & $* * *$ & & \\
\hline \multirow{6}{*}{ SRHRM } & SH1 & 0.783 & 0.613 & - & - & \multirow{6}{*}{0.904} & \multirow{6}{*}{0.612} \\
\hline & $\mathrm{SH} 2$ & 0.805 & 0.648 & 19.802 & $* * *$ & & \\
\hline & $\mathrm{SH} 3$ & 0.752 & 0.566 & 18.370 & $* * *$ & & \\
\hline & $\mathrm{SH} 4$ & 0.726 & 0.527 & 17.507 & $* * *$ & & \\
\hline & SH5 & 0.815 & 0.664 & 20.233 & $* * *$ & & \\
\hline & SH6 & 0.809 & 0.654 & 20.252 & $* * *$ & & \\
\hline \multirow{8}{*}{ Moral Efficacy } & ME1 & 0.774 & 0.599 & - & - & \multirow{8}{*}{0.911} & \multirow{8}{*}{0.562} \\
\hline & ME2 & 0.839 & 0.705 & 20.834 & $* * *$ & & \\
\hline & ME3 & 0.631 & 0.398 & 14.908 & $* * *$ & & \\
\hline & ME4 & 0.800 & 0.641 & 19.624 & $* * *$ & & \\
\hline & ME5 & 0.768 & 0.590 & 18.703 & $* * *$ & & \\
\hline & ME6 & 0.699 & 0.489 & 16.628 & $* * *$ & & \\
\hline & ME7 & 0.745 & 0.556 & 18.102 & $* * *$ & & \\
\hline & ME9 & 0.722 & 0.521 & 17.392 & $* * *$ & & \\
\hline \multirow{7}{*}{ Felt Obligation } & FO1 & 0.841 & 0.707 & - & - & \multirow{7}{*}{0.925} & \multirow{7}{*}{0.641} \\
\hline & $\mathrm{FO} 2$ & 0.687 & 0.472 & 17.876 & $* * *$ & & \\
\hline & FO3 & 0.731 & 0.534 & 19.498 & $* * *$ & & \\
\hline & $\mathrm{FO} 4$ & 0.881 & 0.776 & 26.213 & $* * *$ & & \\
\hline & FO5 & 0.820 & 0.672 & 23.226 & $* * *$ & & \\
\hline & FO6 & 0.834 & 0.695 & 23.721 & $* * *$ & & \\
\hline & FO7 & 0.792 & 0.628 & 21.873 & $* * *$ & & \\
\hline \multirow{9}{*}{ Empathy } & EP1 & 0.713 & 0.508 & - & - & \multirow{9}{*}{0.917} & \multirow{9}{*}{0.553} \\
\hline & EP2 & 0.672 & 0.451 & 14.947 & $* * *$ & & \\
\hline & EP3 & 0.678 & 0.460 & 15.196 & $* * *$ & & \\
\hline & EP5 & 0.797 & 0.635 & 17.731 & $* * *$ & & \\
\hline & EP6 & 0.718 & 0.515 & 16.036 & $* * *$ & & \\
\hline & EP7 & 0.883 & 0.779 & 19.525 & $* * *$ & & \\
\hline & EP8 & 0.702 & 0.493 & 15.676 & $* * *$ & & \\
\hline & EP9 & 0.794 & 0.631 & 17.770 & $* * *$ & & \\
\hline & EP10 & 0.712 & 0.507 & 15.781 & $* * *$ & & \\
\hline \multirow{3}{*}{ Eco-initiatives } & OE1 & 0.832 & 0.692 & - & - & \multirow{3}{*}{0.863} & \multirow{3}{*}{0.679} \\
\hline & OE2 & 0.873 & 0.762 & 22.183 & $* * *$ & & \\
\hline & OE3 & 0.763 & 0.582 & 19.235 & $* * *$ & & \\
\hline \multirow{4}{*}{ Eco-civic Engagement } & $\mathrm{OE} 4$ & 0.860 & 0.740 & - & - & \multirow{4}{*}{0.890} & \multirow{4}{*}{0.670} \\
\hline & OE5 & 0.763 & 0.582 & 20.437 & $* * *$ & & \\
\hline & OE6 & 0.871 & 0.759 & 25.264 & $* * *$ & & \\
\hline & OE7 & 0.775 & 0.601 & 21.030 & $* * *$ & & \\
\hline \multirow{3}{*}{ Eco-helping } & OE8 & 0.807 & 0.651 & - & - & \multirow{3}{*}{0.845} & \\
\hline & OE9 & 0.809 & 0.654 & 18.785 & $* * *$ & & 0.645 \\
\hline & OE10 & 0.794 & 0.631 & 18.657 & $* * *$ & & \\
\hline
\end{tabular}

Based on Jackson et al.'s [90] recommendations, we used the 10 most frequently reported fit indices in previous CFA studies to evaluate the overall model fit in the present study, including the chi-square $\left(\chi^{2}\right)$, degrees of freedom $(d f), \chi^{2} / d f$ ratio, standardized root mean square residual (RMSR), root mean square error of approximation (RMSEA), goodness-of-fit index (GFI), adjusted goodness-of-fit index (AGFI), normed fit index (NFI), non-normed fit index (NNFI), and comparative fit index (CFI). Generally, $\chi^{2} / d f$ ratio between 1 and 3 indicates that the model fits the data well. RMSEA values in the $0-0.08$ range and SRMR values in the $0-0.05$ range are considered as evidence of good fit, with smaller values indicating better model fit. Values of the other fit indices-including GFI, AGFI, 
NFI, NNFI, and CFI-in the 0.90-1.0 range represent good model fit, with larger values indicating better model fit [91].

Table 4 reports the values of the fit indices for the CFA model $\left(\chi^{2}=927.214 ; d f=727\right.$; $\chi^{2} / d f=1.275 ;$ RMSEA $=0.023 ;$ SRMR $=0.033 ;$ GFI $=0.922 ;$ AGFI $=0.912 ; \mathrm{NFI}=0.933$; $\mathrm{NNFI}=0.983$; CFI $=0.985$ ). All fit indices conformed to the common criteria of SEM research. Thus, we concluded that the measurement model fit the sample data well.

Table 4. Measurement Model Fit Statistics.

\begin{tabular}{ccccccccccc}
\hline Fit Index & $\chi^{2}$ & $d f$ & $\chi^{2} / d f$ & RMSEA & SRMR & GFI & AGFI & NFI & NNFI & CFI \\
\hline Common & - & - & $<3$ & $<0.08$ & $<0.05$ & $>0.90$ & $>0.90$ & $>0.90$ & $>0.90$ & $>0.90$ \\
Criterion & - & 727 & 1.275 & 0.023 & 0.033 & 0.922 & 0.912 & 0.933 & 0.983 & 0.985 \\
Measured Value & 927.214 & 727 & \\
\hline
\end{tabular}

Table 5 shows the reliability analysis results for all scales. Cronbach's alpha coefficients ranged between 0.890 and 0.924 , indicating good internal consistency for all scales.

Table 5. Reliability Analysis Results.

\begin{tabular}{ccc}
\hline Variable & Cronbach's Alpha & $\boldsymbol{n}$ of Items \\
\hline Perceived SRHRM & 0.902 & 6 \\
Moral Efficacy & 0.910 & 8 \\
Felt Obligation & 0.924 & 7 \\
Empathy & 0.916 & 9 \\
OCBE & 0.890 & 10 \\
\hline
\end{tabular}

\subsection{Correlational Analysis}

As shown in Table 6, SRHRM (the independent variable in the research model) had significant positive correlations with moral efficacy $(r=0.482, p<0.001)$, felt obligation $(r=0.446, p<0.001)$, empathy $(r=0.402, p<0.001)$, and OCBE $(r=0.442, p<0.001)$. All mediating variables - moral efficacy, felt obligation, and empathy-were significantly positively correlated with the dependent variable OCBE (respectively, $r=0.422, p<0.001$; $r=0.440, p<0.001 ; r=0.409, p<0.001$ ). These significant correlations among the variables of interest preliminarily supported our general hypothesis and provided a solid foundation for specific hypothesis testing.

Table 6. Means, Standard Deviations, and Correlations $(n=535)$.

\begin{tabular}{lccccccc}
\hline \multicolumn{1}{c}{ Variable } & $\mathbf{M}$ & SD & $\mathbf{1}$ & $\mathbf{2}$ & $\mathbf{3}$ & $\mathbf{4}$ & $\mathbf{5}$ \\
\hline 1. Gender & 0.477 & 0.500 & 1 & & & & \\
2. Perceived SRHRM & 4.630 & 1.621 & 0.074 & 1 & & & \\
3. Moral Efficacy & 4.890 & 1.361 & 0.004 & $0.482^{* * *}$ & 1 & & \\
4. Felt Obligation & 4.561 & 1.631 & 0.007 & $0.446^{* * *}$ & $0.346^{* * *}$ & 1 & 1 \\
5. Empathy & 4.267 & 1.524 & 0.031 & $0.402^{* * *}$ & $0.269^{* * *}$ & $0.279^{* * *}$ & 1 \\
6. OCB-E & 4.757 & 1.314 & 0.021 & $0.442^{* * *}$ & $0.422^{* * *}$ & $0.440^{* * *}$ & $0.409^{* * *}$ \\
\hline
\end{tabular}

\subsection{Hypothesis Testing}

\subsubsection{Main Effect of SRHRM on OCB-E}

To examine the relationship between SRHRM and OCBE, the hierarchical multiple regression method was adopted and processed via SPSS 25.0 in this study. The results are presented in Table 7 . All control variables were transformed into dummy variables and then entered into model 1 of hierarchical regression analysis. Then, the independent variable SRHRM was added into Model 2 to identify the effects of SRHRM on the outcome variable OCBE. After adding SRHRM into Model 2, the results in Table 2 show that SRHRM 
had a significant positive effect on OCBE $(\beta=0.436, p<0.001)$ and the $\mathrm{R} 2$ of the model also increased from 0.037 to 0.222 , which supported Hypothesis 1 .

Table 7. Hierarchical Regression Results $(n=535)$.

\begin{tabular}{ccc}
\hline Variable & OCBE \\
\cline { 2 - 3 } & Model 1 & Model 2 \\
\hline Control Variable \\
\hline Gender (Female) & 0.020 & -0.008 \\
Age_under 20 & 0.072 & 0.047 \\
Age_20s & 0.110 & 0.083 \\
Age_40s & -0.010 & -0.004 \\
Age_above 50 & 0.012 & 0.004 \\
Edu_High & $-0.112^{*}$ & $-0.104^{*}$ \\
Edu_College & -0.019 & -0.014 \\
Edu_MA & -0.012 & -0.007 \\
Tenure_less 1 & -0.065 & -0.054 \\
Tenure_1 to 3 & $-0.1233^{*}$ & $-0.098^{*}$ \\
Tenure_7 to 10 & 0.047 & 0.028 \\
Tenure_more 10 & 0.034 & 0.062 \\
Position_JuniorMgr & 0.026 & 0.019 \\
Position_IntermMgr & -0.009 & 0.010 \\
Position_SeniorMgr & -0.062 & -0.031 \\
\hline & Independent Variable & \\
\hline Perceived SRHRM & & $0.436^{* * *}$ \\
R ${ }^{2}$ & 0.037 & 0.222 \\
Adjusted R ${ }^{2}$ & 0.009 & 0.198 \\
R $^{2}$ Change & 0.037 & 0.185 \\
F & 1.339 & $9.244^{* * *}$ \\
F Change & 1.339 & $123.099^{* * *}$ \\
\hline Omitted variables are Age_30s, Edu_BA, Tenure_4 to 6, Position_staff. ${ }^{*} p<0.05, * * * 0$ & 0.001. \\
& &
\end{tabular}

\subsubsection{Multiple Mediating Effect in Relationship between SRHRM and OCBE}

Table 8 and Figure 2 report the coefficients of all paths in the multiple-mediator model between SRHRM and OCB-E. SRHRM had significant positive effects on moral efficacy $(\beta=0.402, t=13.753, p<0.001)$, felt obligation $(\beta=0.447, t=12.032, p<0.001)$, and empathy $(\beta=0.374, t=10.516, p<0.001)$. Likewise, moral efficacy $(\beta=0.212, t=5.175, p<0.001)$, felt obligation $(\beta=0.195, t=5.776, p<0.001)$, and empathy $(\beta=0.206, t=5.796, p<0.001)$ all had significant positive effects on OCBE. Moreover, SRHRM had a significant positive effect on OCBE ( $\beta=0.357, t=11.806, p<0.001)$, and upon entering moral efficacy, felt obligation, and empathy into the model, the direct positive effect of SRHRM on OCBE was reduced considerably $(\beta=0.107, t=2.789, p<0.01)$, indicating the mediating effects of each variable. Thus, Hypothesis 1 was supported.

Table 8. Path Coefficients of the Multiple-Mediator Model between SRHRM and OCB-E $(n=535)$.

\begin{tabular}{|c|c|c|c|c|c|c|c|}
\hline \multirow{2}{*}{ Path } & \multirow{2}{*}{ B } & \multirow{2}{*}{ S.E. } & \multirow{2}{*}{$t$-Value } & \multicolumn{2}{|c|}{$95 \%$ CI } & \multirow{2}{*}{$\mathbf{R}^{2}$} & \multirow{2}{*}{$\mathbf{F}$} \\
\hline & & & & LLCI & ULCI & & \\
\hline SRHRM $\rightarrow$ Moral Efficacy & 0.402 & 0.029 & $13.753^{* * *}$ & 0.345 & 0.460 & 0.307 & $48.674^{* * *}$ \\
\hline SRHRM $\rightarrow$ Felt Obligation & 0.447 & 0.037 & $12.032 * * *$ & 0.374 & 0.520 & 0.222 & $26.752 * * *$ \\
\hline SRHRM $\rightarrow$ Empathy & 0.374 & 0.036 & $10.516^{* * *}$ & 0.304 & 0.444 & 0.208 & $25.855^{* * *}$ \\
\hline Moral Efficacy $\rightarrow$ OCB-E & 0.212 & 0.041 & $5.175^{* * *}$ & 0.131 & 0.292 & & \\
\hline Felt Obligation $\rightarrow$ OCB-E & 0.195 & 0.034 & $5.776^{* * *}$ & 0.129 & 0.262 & & \\
\hline Empathy $\rightarrow$ OCB-E & 0.206 & 0.036 & $5.796^{* * *}$ & 0.136 & 0.276 & 0.355 & $43.183^{* * *}$ \\
\hline SRHRM $\rightarrow$ OCB-E (direct) & 0.107 & 0.038 & $2.789 * *$ & 0.032 & 0.182 & & \\
\hline SRHRM $\rightarrow$ OCB-E (total) & 0.357 & 0.030 & $11.806^{* * *}$ & 0.297 & 0.416 & 0.210 & $26.821 * * *$ \\
\hline
\end{tabular}

${ }^{* * *} p<0.001 . \mathrm{CI}=$ Confidence Interval; LLCI = Lower Limit Confidence Interval; ULCI = Upper Limit Confidence Interval. 


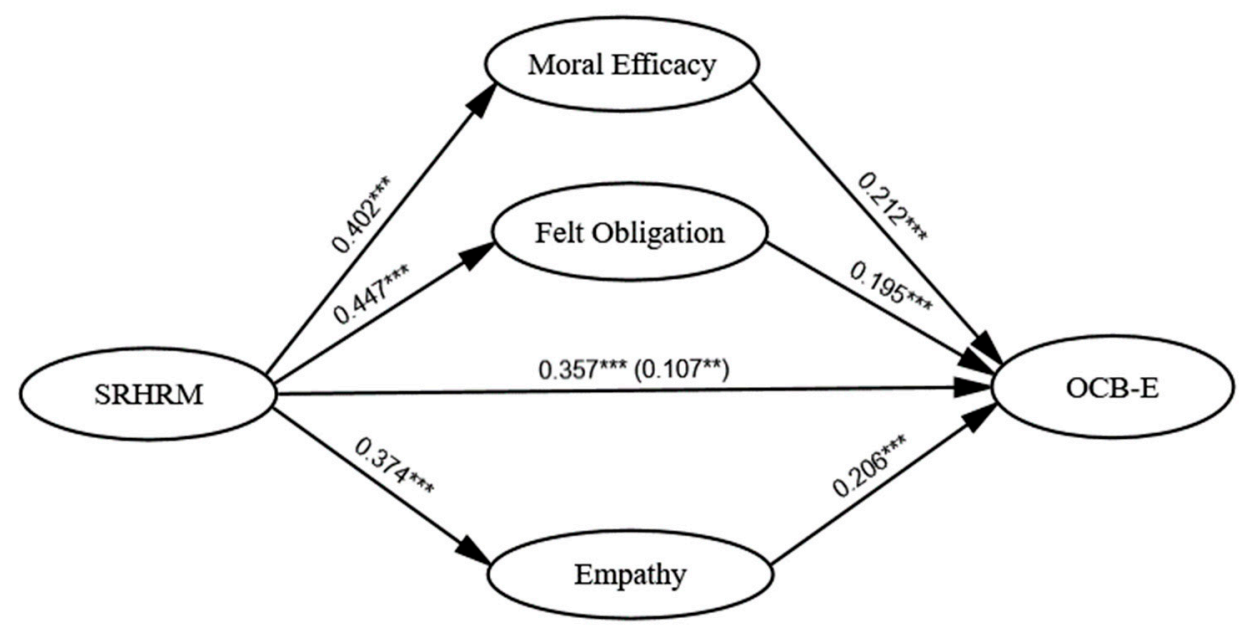

Figure 2. Multiple-Mediator Model of Relationship between SRHRM and OCBE. ${ }^{* *} p<0.01$, *** $p<0.001$. ( ): Direct effect.

Table 9 reports the analysis results of the multiple mediating effects of moral efficacy, felt obligation, and empathy on the relationship between SRHRM and OCBE. The bootstrap $95 \%$ confidence interval $(0.200-0.304)$ of the total indirect effects $(\beta=0.250)$ did not contain 0 , indicating that the total mediating effects in the model were significant. Further, the bootstrap 95\% confidence intervals corresponding to the indirect effects of SRHRM on OCBE through moral efficacy $(\beta=0.085)$, felt obligation $(\beta=0.087)$, and empathy ( $\beta=0.077)$ did not contain 0 (respectively, 0.052-0.121, 0.057-0.120, and 0.051-0.109), indicating that mediating effects of each were statistically significant. When comparing the effect sizes of the three mediating paths in pairs, the bootstrap 95\% confidence intervals of the effect differences all contained 0 (respectively, $-0.050-0.045,-0.037-0.055$, and $-0.036-0.054$ ), indicating that there were no significant differences in the mediating effects of moral efficacy, felt obligation, and empathy; these effects accounted for $23.81 \%, 24.37 \%$, and $21.57 \%$ of the total mediating effect (70.03\%), respectively. Therefore, Hypotheses 2,3 , and 4 all were supported.

Table 9. Multiple Mediating Effects in Relationship between SRHRM and OCBE $(n=535)$.

\begin{tabular}{|c|c|c|c|c|c|c|}
\hline \multirow{2}{*}{ Path } & \multirow{2}{*}{ Effect } & \multirow{2}{*}{ S.E. } & \multirow{2}{*}{$t$-Value } & \multicolumn{2}{|c|}{$95 \% \mathrm{CI}$} & \multirow{2}{*}{$\begin{array}{l}\text { Proportion Via } \\
\text { Mediation }\end{array}$} \\
\hline & & & & LLCI & ULCI & \\
\hline \multicolumn{7}{|c|}{ Total Effects } \\
\hline SRHRM $\rightarrow$ OCB-E & 0.357 & 0.030 & $11.806^{* * *}$ & 0.297 & 0.416 & - \\
\hline \multicolumn{7}{|c|}{ Direct Effects } \\
\hline SRHRM $\rightarrow$ OCB-E & 0.107 & 0.038 & $2.789 * *$ & 0.031 & 0.182 & - \\
\hline \multicolumn{7}{|c|}{ Indirect Effects } \\
\hline SRHRM $\rightarrow$ Moral efficacy $\rightarrow$ OCB-E & 0.085 & 0.017 & - & 0.052 & 0.121 & $23.81 \%$ \\
\hline SRHRM $\rightarrow$ Felt obligation $\rightarrow$ OCB-E & 0.087 & 0.016 & - & 0.057 & 0.120 & $24.37 \%$ \\
\hline SRHRM $\rightarrow$ Empathy $\rightarrow$ OCB-E & 0.077 & 0.015 & - & 0.051 & 0.109 & $21.57 \%$ \\
\hline Total Indirect Effects & 0.250 & 0.027 & - & 0.200 & 0.304 & $70.03 \%$ \\
\hline \multicolumn{7}{|c|}{ Contrasts } \\
\hline Mediation 1 versus Mediation 2 & -0.002 & 0.024 & - & -0.050 & 0.045 & - \\
\hline Mediation 1 versus Mediation 3 & 0.008 & 0.022 & - & -0.037 & 0.055 & - \\
\hline Mediation 2 versus Mediation 3 & 0.010 & 0.023 & - & -0.036 & 0.054 & - \\
\hline
\end{tabular}

${ }^{* *} p<0.01,{ }^{* * *} p<0.001$. CI $=$ Confidence Interval; LLCI = Lower Limit Confidence Interval; ULCI = Upper Limit Confidence Interval. Mediation $1=$ SRHRM $\rightarrow$ Moral efficacy $\rightarrow$ OCB-E; Mediation $2=$ SRHRM $\rightarrow$ Felt obligation $\rightarrow$ OCB-E; Mediation $3=$ SRHRM $\rightarrow$ Empathy $\rightarrow$ OCB-E. 


\section{Discussion}

\subsection{Results Summary}

From the perspective of proactive motivation theory, this study proposed a multiplemediation model to explore the effect of employee perception of SRHRM practice on employees' OCBE and its mechanisms. Based on data from 535 employees of 23 manufacturing companies in China, we uncovered the mediating effects of moral efficacy, felt obligation, and empathy in the relationship between perceived SRHRM and OCBE and can draw several conclusions.

First, this study verified employee perception of SRHRM had significant positive effect on OCBE. Specifically, when employees perceive that their organizations practice SRHRM well, it can encourage employees to engage in socially responsible behaviors such as OCBE. This finding is consistent with the view proposed by Slack et al. [92] that the degree of CSR embedding within an organization will affect employees' participation in CSR initiatives. When organizations clearly convey the value of CSR to employees through SRHRM practice, employees, as the main purveyors of organizations' CSR initiatives, will naturally take initiative to participate in organizational CSR and then engage in more socially responsible behaviors such as OCBE. This conclusion also echoes the view of Ellis [93] that employees' perceptions of CSR impact personal social action.

Second, this study confirmed that moral efficacy, felt obligation, and empathy significantly mediate the influence of perceived SRHRM on OCBE, with no significant differences among the three mediation paths. More specifically, when the organization practices SRHRM effectively, this will enhance employees' belief that they can execute socially responsible behaviors in line with ethical norms, make employees feel obligated to perform socially responsible behaviors as feelings of obligation to the organization increase, and energize employees to engage in further socially responsible behaviors vis-à-vis caring for other stakeholders as their empathy increases. Through the three motivational states for proactive participation in socially responsible behaviors inspired by SRHRM, employees become more willing to engage in socially responsible behaviors such as OCBE.

\subsection{Implications}

This study's findings have several theoretical implications. First, this study expands on existing work on the consequences of SRHRM by exploring the impact of organizations' SRHRM practices on employees' OCBE. In contrast to earlier human resource management systems promoting only organizational interests (e.g., high-performance HRM systems), SRHRM as an organizational policy assumes responsibility for society and promotes social welfare, aiming to improve the organization's overall social performance. In existing studies, scholars have only discussed the notion that SRHRM positively impacts employees' attitudes and behaviors at work, such as organizational commitment, task performance, organizational citizenship behavior, and extra-role helping behavior $[9,10,81,93]$. However, there has been little research exploring the relationship between SRHRM and employees' social performance. This study fills this gap and demonstrates that SRHRM can promote employees' engagement in socially responsible behaviors such as OCB-E. Additionally, this study widened the theoretical basis for SRHRM's mechanism by integrating proactive motivation theory in verifying the mediating effects of moral efficacy, felt obligation, and empathy in the relationship between SRHRM and OCBE.

Second, this study expands current research on the antecedents of OCBE by verifying the positive influence of employee perception of SRHRM practice. This is in line with Luu [94], who found that employees' perceptions of CSR can positively affect their OCBE in a study of employees from the Vietnamese hotel industry; however, there is no research exploring whether SRHRM, as an important practical policy for organizations to fulfill CSR, can promote employees' engagement in OCBEs.

This study's results also have implications for organizational management practice. First, there are implications for CSR and HRM. Nowadays, organizational managers have realized that active CSR initiatives not only can bring considerable financial benefits but 
also have become an important source of competitive advantage. However, many managers still focus on CSR fulfillment only with regard to external stakeholders, thereby ignoring employees' role as the most important internal stakeholders. As organizational CSR initiative participants, practitioners, and observers, employees' initiative and cooperation in CSR activities will directly affect their success and thus the realization of strategic goals for sustainable development [12]. Thus, conveying the importance of CSR and guiding employees to actively participate in CSR initiatives will help organizations gain competitive advantages and achieve strategic sustainability goals. This study's findings suggest that the development and implementation of SRHRM practice are of great significance for addressing this issue. SRHRM practice combines the interests of employees and external stakeholders and constructs an "employee-organization social interest community" system. This is not only important for the successful implementation of CSR projects for external stakeholders but also clearly conveys CSR information to employees, improving their social responsibility awareness and mobilizing their enthusiasm and initiative to participate in workplace CSR activities. Specifically, organizational managers must recruit employees with a strong sense of social responsibility, provide employees with CSR-related training, consider employees' social performance in the performance evaluation process, and link their social performance to promotions and compensation increases. When employees recognize their responsibility and obligation to engage in CSR initiatives through such socially responsible HRM practices, they will naturally perform behaviors like OCBE, creating a win-win situation for employees, the organization, and society.

Second, this study provides implications for organizations' environmentally sustainable development. Nowadays, it is self-evident that environmental protection and ethical issues have an important impact on the survival and development of organizations. Thus, organizations should pay close attention to the issue of how to increase employees' environmental protection behaviors in the workplace. Our results show that SRHRM practice can improve employees' moral efficacy, felt obligation, and empathy, encouraging them to engage in beneficial environmental behaviors beyond job requirements, such as OCBE. Therefore, in daily management practice, organizations can encourage employees' environmental behaviors and discourage unethical behaviors by adopting SRHRM, advancing the organization's sustainable development.

\subsection{Limitations and Directions for Future Studies}

Despite efforts to ensure the theoretical grounding and precision of the overall research process, this study has several limitations, some of which the authors hope can be addressed in future research. First, the sample selection was limited. Practice of SRHRM is not yet universal in China, and it was difficult for us to persuade HR managers of non-practicing firms to join our study. Even though the number of companies we lost due to this reason was not too large (7 out of 30), there is no denying that the resulting sample selection clearly limits generalizability of our findings to the wider universe of all manufacturing companies in China.

Second, the attraction-selection-attrition (ASA) theory suggests a fundamental difficulty in causal interpretation of our findings. According to ASA, individuals are drawn to firms that have values similar to their own. At the same time, firms select applicants that share their values [95]. Thus, it is unclear whether cross-organizational correlation between SRHRM and OCBE reflects a causal impact from the former on the latter or represents the result of a sorting-and-matching process. We note that we are focusing on micro-level SRHRM or employee perceptions of SRHRM, and that there are within-organization variations in the perceptions as well as between-organization variations. To the extent our finding reflects the impacts of the within-organization variations in perceived SRHRM, we may as well claim a causal impact, but we are aware that our finding is confounded by the cross-organizational variations. Perhaps one way to overcome this difficulty is to conduct a longitudinal study with a sufficient interval to trace the impacts of within-company evolutions in the practice of SRHRM. 
Third, we collected data through self-reports of respondents, so it is difficult to completely eliminate the influence of common method variance on the results. Although a longitudinal research design was used, the interval between the two data collection phases was relatively short, potentially distorting the relationships among the variables of interest. Considering that the effects of SRHRM and employees' motivational states and behaviors are usually dynamic, future studies should adopt a more comprehensive longitudinal research design to explore these variables' trends and clarify the causal relationships among them. For example, as recommended by Shen and Benson [9], longitudinal data should be collected at three different timepoints, including before the introduction of any new SRHRM practice, to examine the impact of the introduction and change of SRHRM practices on employees' workplace behaviors. Future research should also adopt experimental designs to more rigorously assess the impact of dynamic changes in SRHRM on employees' workplace behavior.

Fourth, to our regret, our data does not allow us to measure SRHRM practices at the company level. To assuage privacy-related concerns of the respondents, we did not gather information on what company they work for, and as a result, cannot identify groups of workers working for a given company. This means that we are unable to decouple the potentially separate impacts of company-level SRHRM practices and employee perceptions (micro-level SRHRM). Future research should be designed to overcome this weakness.

Finally, this study took place in the Chinese organizational management context, with all data collected from Chinese manufacturing company employees, so there may be some limitations in the generalizability of the findings. Although the degree of openness and contact among countries is increasing with globalization, there remain great differences among countries in terms of CSR norms, SRHRM policies and practices, and culture and values (Shen and Benson, 2016). Therefore, the influencing mechanism of SRHRM on employee behavior revealed in the present study might differ considerably in other countries or cultural contexts. Thus, in future research, it would be desirable to integrate the trend of diversified development and replicate this study in different cultural contexts, such as western countries with small power distance and strong individualism.

Author Contributions: Conceptualization, J.H. and H.K.; methodology and formal analysis, J.H.; writing-original draft preparation, J.H.; writing-review and editing, H.K.; supervision, H.K. All authors have read and agreed to the published version of the manuscript.

Funding: This research received no external funding.

Institutional Review Board Statement: Ethical review and approval were waived for this study, as the survey conducted in the study does not include ethically sensitive content.

Informed Consent Statement: Informed consent was obtained from all subjects involved in the study.

Data Availability Statement: Data is available from authors upon request.

Conflicts of Interest: The authors declare no conflict of interest.

\section{References}

1. Daily, B.F.; Bishop, J.W.; Govindarajulu, N. A conceptual model for organizational citizenship behavior directed toward the environment. Bus. Soc. 2009, 48, 243-256. [CrossRef]

2. Ones, D.S.; Dilchert, S. Environmental sustainability at work: A call to action. Ind. Organ. Psychol. 2012, 5, 444-466. [CrossRef]

3. Paillé, P.; Boiral, O.; Chen, Y. Linking environmental management practices and organizational citizenship behaviour for the environment: A social exchange perspective. Int. J. Hum. Resour. Manag. 2013, 24, 3552-3575. [CrossRef]

4. Boiral, O.; Paillé, P. Organizational citizenship behaviour for the environment: Measurement and validation. J. Bus. Ethics 2011, 109, 431-445. [CrossRef]

5. Lamm, E.; Tosti-Kharas, J.; Williams, E.G. Read this article, but don't print it: Organizational citizenship behavior toward the environment. Group Organ. Manag. 2013, 38, 163-197. [CrossRef]

6. Paillé, P.; Chen, Y.; Boiral, O.; Jin, J. The impact of human resource management on environmental performance: An employeelevel study. J. Bus. Ethics 2014, 121, 451-466. [CrossRef]

7. Raineri, N.; Paillé, P. Linking corporate policy and supervisory support with environmental citizenship behaviors: The role of employee environmental beliefs and commitment. J. Bus. Ethics 2016, 137, 129-148. [CrossRef] 
8. Aguinis, H.; Glavas, A. What we know and don't know about corporate social responsibility: A review and research agenda. J. Manag. 2012, 38, 932-968. [CrossRef]

9. Shen, J.; Benson, J. When CSR is a social norm: How socially responsible human resource management affects employee work behavior. J. Manag. 2016, 42, 1723-1746. [CrossRef]

10. Shen, J.; Zhu, J. Effects of socially responsible human resource management on employee organizational commitment. Int. J. Hum. Resour. Manag. 2011, 22, 3020-3035. [CrossRef]

11. Parker, S.K.; Bindl, U.K.; Strauss, K. Making things happen: A model of proactive motivation. J. Manag. 2010, 36, 827-856. [CrossRef]

12. Mirvis, P.; Googins, B. Engaging employees as social innovators. Calif. Manag. Rev. 2018, 60, 25-50. [CrossRef]

13. Ones, D.S.; Dilchert, S. Employee green behaviors. Manag. Hum. Resour. Environ. Sustain. 2012, 32, 85-116.

14. Daily, B.F.; Bishop, J.W.; Massoud, J.A. The role of training and empowerment in environmental performance. Int. J. Oper. Prod. Manag. 2012, 32, 631-647. [CrossRef]

15. Erdogan, B.; Bauer, T.N.; Taylor, S. Management commitment to the ecological environment and employees: Implications for employee attitudes and citizenship behaviors. Hum. Relat. 2015, 68, 1669-1691. [CrossRef]

16. Hameed, Z.; Khan, I.U.; Islam, T.; Sheikh, Z.; Naeem, R.M. Do green HRM practices influence employees' environmental performance? Int. J. Manpow. 2020, 41, 1061-1079. [CrossRef]

17. Pham, T.N.; Phan, Q.P.T.; Tučková, Z.; Vo, T.N.; Nguyen, L.H. Enhancing the organizational citizenship behavior for the environment: The roles of green training and organizational culture. Manag. Mark. Chall. Knowl. Soc. 2018, 13, 1174-1189. [CrossRef]

18. Boiral, O.; Raineri, N.; Talbot, D. Managers' citizenship behaviors for the environment: A developmental perspective. J. Bus. Ethics 2018, 149, 395-409. [CrossRef]

19. Han, Z.; Wang, Q.; Yan, X. How responsible leadership predicts organizational citizenship behavior for the environment in China. Leadersh. Organ. Dev. J. 2019, 40, 305-318. [CrossRef]

20. Graves, L.M.; Sarkis, J.; Zhu, Q. How transformational leadership and employee motivation combine to predict employee proenvironmental behaviors in China. J. Environ. Psychol. 2013, 35, 81-91. [CrossRef]

21. Luu, T.T. Green human resource practices and organizational citizenship behavior for the environment: The roles of collective green crafting and environmentally specific servant leadership. J. Sustain. Tour. 2019, 27, 1167-1196. [CrossRef]

22. Afsar, B.; Badir, Y.; Kiani, U.S. Linking spiritual leadership and employee pro-environmental behavior: The influence of workplace spirituality, intrinsic motivation, and environmental passion. J. Environ. Psychol. 2016, 45, 79-88. [CrossRef]

23. Gousse-Lessard, A.S.; Vallerand, R.J.; Carbonneau, N.; Lafrenière, M.A.K. The role of passion in mainstream and radical behaviors: A look at environmental activism. J. Environ. Psychol. 2013, 35, 18-29. [CrossRef]

24. Tahir, R.; Athar, M.R.; Afzal, A. The impact of greenwashing practices on green employee behaviour: Mediating role of employee value orientation and green psychological climate. Cogent Bus. Manag. 2020, 7, 1781996. [CrossRef]

25. Gilal, F.G.; Ashraf, Z.; Gilal, N.G.; Gilal, R.G.; Channa, N.A. Promoting environmental performance through green human resource management practices in higher education institutions: A moderated mediation model. Corp. Soc. Responsib. Environ. Manag. 2019, 26, 1579-1590. [CrossRef]

26. Wang, X.; Zhou, K.; Liu, W. Value congruence: A study of green transformational leadership and employee green behavior. Front. Psychol. 2018, 9, 1946. [CrossRef] [PubMed]

27. Bowen, H.R. Social Responsibilities of the Businessman; Harper: New York, NY, USA, 1953.

28. Carroll, A.B. Corporate social responsibility: Evolution of a definitional construct. Bus. Soc. 1999, 38, 268-295. [CrossRef]

29. Basu, K.; Palazzo, G. Corporate social responsibility: A process model of sensemaking. Acad. Manag. Rev. 2008, 33, 122-136. [CrossRef]

30. Porter, M.E.; Kramer, M.R. The competitive advantage of corporate philanthropy. Harv. Bus. Rev. 2002, 80, 56-68. [PubMed]

31. Lii, Y.-S.; Lee, M. Doing right leads to doing well: When the type of CSR and reputation interact to affect consumer evaluations of the firm. J. Bus. Ethics 2012, 105, 69-81. [CrossRef]

32. Wang, T.; Bansal, P. Social responsibility in new ventures: Profiting from a long-term orientation. Strateg. Manag. J. 2012, 33, 1135-1153. [CrossRef]

33. Carnahan, S.; Kryscynski, D.; Olson, D. When does corporate social responsibility reduce employee turnover? Evidence from attorneys before and after 9/11. Acad. Manag. J. 2017, 60, 1932-1962. [CrossRef]

34. Jones, D.A.; Willness, C.R.; Madey, S. Why are job seekers attracted by corporate social performance? Experimental and field tests of three signal-based mechanisms. Acad. Manag. J. 2014, 57, 383-404. [CrossRef]

35. Greening, D.W.; Turban, D.B. Corporate social performance as a competitive advantage in attracting a quality workforce. Bus. Soc. 2000, 39, 254-280. [CrossRef]

36. Voegtlin, C.; Greenwood, M. Corporate social responsibility and human resource management: A systematic review and conceptual analysis. Hum. Resour. Manag. Rev. 2016, 26, 181-197. [CrossRef]

37. Morgeson, F.P.; Aguinis, H.; Waldman, D.A.; Siegel, D.S. Extending corporate social responsibility research to the human resource management and organizational behavior domains: A look to the future. Pers. Psychol. 2013, 66, 805-824. [CrossRef]

38. Rowan, J.R. The moral foundation of employee rights. J. Bus. Ethics 2000, 24, 355-361. [CrossRef] 
39. Ahmad, N.; Ullah, Z.; Mahmood, A.; Ariza-Montes, A.; Vega-Muñoz, A.; Han, H.; Scholz, M. Corporate social responsibility at the micro-level as a "new organizational value" for sustainability: Are females more aligned towards it? Int. J. Environ. Res. Public Health 2021, 18, 2165. [CrossRef] [PubMed]

40. Zhang, Z.; Wang, J.; Jia, M. Multilevel Examination of How and When Socially Responsible Human Resource Management Improves the Well-Being of Employees. J. Bus. Ethics 2021, 1-17. [CrossRef]

41. Wang, Y.; Xu, S.; Wang, Y. The consequences of employees' perceived corporate social responsibility: A meta-analysis. Bus. Ethics A Eur. Rev. 2020, 29, 471-496. [CrossRef]

42. Aguilera, R.V.; Rupp, D.E.; Williams, C.A.; Ganapathi, J. Putting the S back in corporate social responsibility: A multilevel theory of social change in organizations. Acad. Manag. Rev. 2007, 32, 836-863. [CrossRef]

43. Blau, P.M. Exchange and Power in Social Life; John Wiley \& Sons: New York, NY, USA, 1964.

44. Ramus, C.A.; Steger, U. The roles of supervisory support behaviors and environmental policy in employee "ecoinitiatives" at leading-edge European companies. Acad. Manag. J. 2000, 43, 605-626.

45. Ashforth, B.E.; Mael, F. Social identity theory and the organization. Acad. Manag. Rev. 1989, 14, 20-39. [CrossRef]

46. Riketta, M. Organizational identification: A meta-analysis. J. Vocat. Behav. 2005, 66, 358-384. [CrossRef]

47. Mozes, M.; Josman, Z.; Yaniv, E. Corporate social responsibility organizational identification and motivation. Soc. Responsib. J. 2011, 7, 310-325. [CrossRef]

48. Tian, Q.; Robertson, J.L. How and when does perceived CSR affect employees' engagement in voluntary pro-environmental behavior? J. Bus. Ethics 2017, 155, 399-412. [CrossRef]

49. Hobfoll, S.E. The influence of culture, community, and the nested-self in the stress process: Advancing conservation of resources theory. Appl. Psychol. 2001, 50, 337-421. [CrossRef]

50. Bandura, A. Self-efficacy: Toward a unifying theory of behavioral change. Psychol. Rev. 1977, 84, 191-215. [CrossRef]

51. Liberman, N.; Trope, Y. The role of feasibility and desirability considerations in near and distant future decisions: A test of temporal construal theory. J. Personal. Soc. Psychol. 1998, 75, 5-18. [CrossRef]

52. Ilies, R.; Judge, T.A. Goal regulation across time: The effects of feedback and affect. J. Appl. Psychol. 2005, 90, 453-467. [CrossRef]

53. Lee, H.W.; Pak, J.; Kim, S.; Li, L.Z. Effects of human resource management systems on employee proactivity and group innovation. J. Manag. 2019, 45, 819-846. [CrossRef]

54. Hong, Y.; Liao, H.; Raub, S.; Han, J.H. What it takes to get proactive: An integrative multilevel model of the antecedents of personal initiative. J. Appl. Psychol. 2016, 101, 687-701. [CrossRef]

55. Hannah, S.T.; Avolio, B.J.; May, D.R. Moral maturation and moral conation: A capacity approach to explaining moral thought and action. Acad. Manag. Rev. 2011, 36, 663-685.

56. Xu, S.; Van Hoof, H.; Serrano, A.L.; Fernandez, L.; Ullauri, N. The role of coworker support in the relationship between moral efficacy and voice behavior: The case of hospitality students in Ecuador. J. Hum. Resour. Hosp. Tour. 2017, 16, 252-269. [CrossRef]

57. Schaubroeck, J.M.; Hannah, S.T.; Avolio, B.J.; Kozlowski, S.W.; Lord, R.G.; Treviño, L.K.; Peng, A.C. Embedding ethical leadership within and across organization levels. Acad. Manag. J. 2012, 55, 1053-1078. [CrossRef]

58. Kim, D.; Vandenberghe, C. Ethical leadership and team ethical voice and citizenship behavior in the military: The roles of team moral efficacy and ethical climate. Group Organ. Manag. 2020, 45, 514-555. [CrossRef]

59. May, D.R.; Luth, M.T.; Schwoerer, C.E. The influence of business ethics education on moral efficacy, moral meaningfulness, and moral courage: A quasi-experimental study. J. Bus. Ethics 2014, 124, 67-80. [CrossRef]

60. Kundu, S.C.; Gahlawat, N. Effects of CSR-focused HRM on employees' satisfaction: A study of Indian organisations. J. Strateg. Hum. Resour. Manag. 2015, 4, 42-48. [CrossRef]

61. Eisenberger, R.; Armeli, S.; Rexwinkel, B.; Lynch, P.D.; Rhoades, L. Reciprocation of perceived organizational support. J. Appl. Psychol. 2001, 86, 42-51. [CrossRef] [PubMed]

62. Cropanzano, R.; Mitchell, M.S. Social exchange theory: An interdisciplinary review. J. Manag. 2005, 31, 874-900. [CrossRef]

63. Paillé, P.; Valéau, P. "I don't owe you, but I am committed”: Does felt obligation matter on the effect of green training on employee environmental commitment? Organ. Environ. 2021, 34, 123-144. [CrossRef]

64. Shore, L.M.; Barksdale, K. Examining degree of balance and level of obligation in the employment relationship: A social exchange approach. J. Organ. Behav. 1998, 19, 731-744. [CrossRef]

65. Yu, C.; Frenkel, S.J. Explaining task performance and creativity from perceived organizational support theory: Which mechanisms are more important? J. Organ. Behav. 2013, 34, 1165-1181. [CrossRef]

66. Albrecht, S.L.; Su, M.J. Job resources and employee engagement in a Chinese context: The mediating role of job meaningfulness, felt obligation and positive mood. Int. J. Bus. Emerg. Mark. 2012, 4, 277-292. [CrossRef]

67. Fuller, J.B.; Marler, L.E.; Hester, K. Promoting felt responsibility for constructive change and proactive behavior: Exploring aspects of an elaborated model of work design. J. Organ. Behav. 2006, 27, 1089-1120. [CrossRef]

68. He, H.; Pham, H.Q.; Baruch, Y.; Zhu, W. Perceived organizational support and organizational identification: Joint moderating effects of employee exchange ideology and employee investment. Int. J. Hum. Resour. Manag. 2014, 25, 2772-2795. [CrossRef]

69. Tian, X.; Li, R. Can self-sacrificial leadership promote employee proactive behavior? The mediating effect of felt obligation and its boundary conditions. Acta Psychol. Sin. 2015, 47, 1472-1485. [CrossRef]

70. Basit, A.A. Trust in supervisor and job engagement: Mediating effects of psychological safety and felt obligation. J. Psychol. 2017, 151, 701-721. [CrossRef] [PubMed] 
71. Lorinkova, N.M.; Perry, S.J. The importance of group-focused transformational leadership and felt obligation for helping and group performance. J. Organ. Behav. 2019, 40, 231-247. [CrossRef]

72. Davis, M.H. Measuring individual differences in empathy: Evidence for a multidimensional approach. J. Personal. Soc. Psychol. 1983, 44, 113-126. [CrossRef]

73. Batson, C.D.; Shaw, L.L. Encouraging words concerning the evidence for altruism. Psychol. Inq. 1991, 2, 159-168. [CrossRef]

74. Duan, C.; Hill, C.E. The current state of empathy research. J. Couns. Psychol. 1996, 43, 261-274. [CrossRef]

75. Dietz, J.; Kleinlogel, E.P. Wage cuts and managers' empathy: How a positive emotion can contribute to positive organizational ethics in difficult times. J. Bus. Ethics 2014, 119, 461-472. [CrossRef]

76. Atkins, P.W.; Parker, S.K. Understanding individual compassion in organizations: The role of appraisals and psychological flexibility. Acad. Manag. Rev. 2012, 37, 524-546. [CrossRef]

77. Eisenberg, N.; Miller, P.A. The relation of empathy to prosocial and related behaviors. Psychol. Bull. 1987, 101, 91-119. [CrossRef]

78. Hoffman, M.L. Empathy and justice motivation. Motiv. Emot. 1990, 14, 151-172. [CrossRef]

79. Joireman, J.; Kamdar, D.; Daniels, D.; Duell, B. Good citizens to the end? It depends: Empathy and concern with future consequences moderate the impact of a short-term time horizon on organizational citizenship behaviors. J. Appl. Psychol. 2006, 91, 1307-1320. [CrossRef] [PubMed]

80. Batson, C.D.; Lishner, D.A.; Cook, J.; Sawyer, S. Similarity and nurturance: Two possible sources of empathy for strangers. Basic Appl. Soc. Psychol. 2005, 27, 15-25. [CrossRef]

81. Shao, D.; Zhou, E.; Gao, P.; Long, L.; Xiong, J. Double-edged effects of socially responsible human resource management on employee task performance and organizational citizenship behavior: Mediating by role ambiguity and moderating by prosocial motivation. Sustainability 2019, 11, 2271. [CrossRef]

82. Berenguer, J. The effect of empathy in proenvironmental attitudes and behaviors. Environ. Behav. 2007, 39, 269-283. [CrossRef]

83. Weiss, H.M.; Cropanzano, R. Affective events theory: A theoretical discussion of the structure, causes and consequences of affective experiences at work. Res. Organ. Behav. Annu. Ser. Anal. Essays Crit. Rev. 1996, 18, 1-74.

84. Podsakoff, P.M.; MacKenzie, S.B.; Podsakoff, N.P. Sources of method bias in social science research and recommendations on how to control it. Annu. Rev. Psychol. 2012, 63, 539-569. [CrossRef]

85. Brislin, R.W. Back-translation for cross-cultural research. J. Cross-Cult. Psychol. 1970, 1, 185-216. [CrossRef]

86. Kish-Gephart, J.J.; Harrison, D.A.; Treviño, L.K. Bad apples, bad cases, and bad barrels: Meta-analytic evidence about sources of unethical decisions at work. J. Appl. Psychol. 2010, 95, 1-31. [CrossRef] [PubMed]

87. Hayes, A.F. Introduction to Mediation, Moderation, and Conditional Process. Analysis: A Regression-Based Approach; Guilford Press: New York, NY, USA, 2013.

88. Richardson, H.A.; Simmering, M.J.; Sturman, M.C. A tale of three perspectives: Examining post hoc statistical techniques for detection and correction of common method variance. Organ. Res. Methods 2009, 12, 762-800. [CrossRef]

89. Hair, J.F.; Black, W.C.; Babin, B.J.; Anderson, R.E.; Tatham, R.L. Multivariate Data Analysis, 5th ed.; Prentice Hall: Hoboken, NJ, USA, 1998.

90. Jackson, D.L.; Gillaspy, J.A., Jr.; Purc-Stephenson, R. Reporting practices in confirmatory factor analysis: An overview and some recommendations. Psychol. Methods 2009, 14, 6-23. [CrossRef] [PubMed]

91. Bentler, P.M.; Bonett, D.G. Significance tests and goodness of fit in the analysis of covariance structures. Psychol. Bull. 1980, 88, 588-606. [CrossRef]

92. Slack, R.; Corlett, S.; Morris, R. Exploring employee engagement with corporate social responsibility: A social exchange perspective on organisational participation. J. Bus. Ethics 2015, 127, 537-548. [CrossRef]

93. Newman, A.; Miao, Q.; Hofman, P.S.; Zhu, C.J. The impact of socially responsible human resource management on employees' organizational citizenship behaviour: The mediating role of organizational identification. Int. J. Hum. Resour. Manag. 2016, 27, 440-455. [CrossRef]

94. Luu, T.T. CSR and organizational citizenship behavior for the environment in hotel industry. Int. J. Contemp. Hosp. Manag. 2017, 29, 2867-2900. [CrossRef]

95. Zhang, L.; Gowan, M.A. Corporate social responsibility, applicants' individual traits, and organizational attraction: A personorganization fit perspective. J. Bus. Psychol. 2012, 27, 345-362. [CrossRef] 